\title{
PURCHASING STRATEGY AND SUPPLY CHAIN MANAGEMENT, THE AIRBUS PRODUCTIVE SYSTEM CASE
}

\author{
FRÉDÉRIC MAZAUD*
}

\begin{abstract}
This paper analyzes the concomitant link between the evolution of purchasing policy and the evolution of supply chain management. The duality of the mode of coordination of the suppliers depends on the relationship between the architect and the first-tier suppliers, according to the strategic degree of their competence. The contribution of this paper is to illuminate the plasticity, the adaptation of the purchasing strategy. The purchasing strategy therefore adapts to the nature of the equipment or systems outsourced, the stakes and expectations are not at all the same. The more complex the product manufactured by the subcontractor, the more the purchasing strategy will seek the mastery of a particular skill. The more standard the product, the more the purchasing strategy aims at reducing costs. The purpose of this paper is twofold. We will show, on the one hand, that there is within the same productive organization a duality of modes of coordination, On the other hand that there is an interaction between the purchasing strategy and these different modes of coordination.
\end{abstract}

Mathematics Subject Classification. 97M40, 97D50, 08B10.

Received February 4, 2018. Accepted January 23, 2019.

\section{INTRODUCTION}

Since the refocusing phenomenon of the 1990s, most computer, automotive, space and aerospace industries have embarked on a process that the literature calls modularity.

Modularity aims to reduce the complexity of a system. The idea is to design the global architecture of a product and break it down into hierarchically nested systems, connected to each other by interfaces, physical and informational, as much as possible standardized.

The literature is abundant and heterogeneous. The founding article by Ulrich [87] analyzes in particular the interrelationships between the components and the global system. Two scenarios are then possible. The interfaces can be coupled, the modification of a component implies a modification of the linked component. These interfaces will be decoupled if a change in one component does not imply a change in the other.

On the organizational level, two major trends emerge from the literature. Baldwin and Clark [8] show through the example of the computer industry (IBM) that the modular architecture can reduce by combining increased outsourcing and division of labor, can reduce production costs and increase efficiency overall.

Keywords. Modularity, systems integration, strategic competences, purchasing strategy, supply chain management, pivot firm, first tier suppliers, airbus.

1 ERPURS (LERASS) - Toulouse 3 University 115D route de Narbonne, BP 67701, 31077 Toulouse Cedex 4, France.

*Corresponding author: frederic.mazaud@iut-tlse3.fr 
Brusoni, Prencipe and Pavitt [14], for their part, consider that the architect of complex systems is gradually becoming an integrator, that is to say that there is an interdependence between him and the first-tier suppliers in the interface specification.

In parallel, Kraljic's founding article (1983) [50] gives birth to Strategic Purchasing Orientation (SPO) [55].

From there will emerge many models relating to the strategic management of customer-supplier relationships $[28,70]$.

However, as Gelderman and Van Weele [40] point out, these matrices remain static and do not take into account the relational dimension of cooperation.

The objective of this research is therefore to analyze the impact of purchasing strategies on supply chain management, with the example of the Airbus Company.

We propose to provide some answers to the question: How does the purchasing strategy influence the supply chain management?

To do this, we must analyse the vertical subcontracting relationships in the framework of complex productions, by insisting on organizational aspects. Then, we will show the transformation of the "Airbus" productive system by focusing on purchasing process and the emergence of a new First-tier supplier's coordination modes.

\section{TheOreticAl BACKGROUnd}

\subsection{The reconfiguration of vertical subcontracting relationships}

\subsubsection{A more and more complex organization of vertical subcontracting relationship}

Traditional analyses of vertical relationships characterize the network-firm as a vertical network structured around the pivot firm (assimilated to a head of network) coordinating the activities of a group of small and medium-sized companies, with the aim of carrying out a specific project [43]. These relationships between this Head of network and these different partners or co-contractors are said cooperation [69]. Inter-firm cooperation, means a durable commitment, between legally independent partners, in a common project in which profits will be shared fairly by relevant firms. Empirically, partnership of vertical sub-contracting relationships will be progressively questioned [3]. From now on, the Orderer gives unilaterally the price, wants a cost and delays decrease, and involves financially its partners. But in the same time, the Orderer sets strict quality standards. Billaudot \& Julien [12] sort out the sub-contracting relationships on a scale from fulfillment of generic product which entails a low intelligence degree (technical division of labour based on price) to fulfillment of the dedicated product (achieved specifically for the customer), which generates a relationship of high intelligence degree (cognitive division of labor based on competences) [67].

\subsubsection{The appearance of an important actor: the pivot-firm}

In this analysis framework, the first-tier supplier, seems to have a large range of responsibilities (conception, production, financing). It has the responsibility to organize its own sub-contracting. This coordinator is localized to an intersection between a speciality sub-contracting relationship (upstream and partnership) and capacity sub-contracting relationship (downstream and a classic arm's length type relationship).

Although they recognize the complexity and the interweaving nature of subcontracting relationships, economists define the pivot-firm as the "formal regulatory organ" of the vertical network, i.e. the main player rather than the intermediary. Thus, since it adheres to the traditional analysis of the "network-firm", the economic notion of "pivot-firm" remains assimilated to that of an architect of network [12]. However, we suggest that this traditional classification now needs to evolve, in order to constitute a truer reflection of current practices. Indeed, this pivot function has been from now on delegated sometimes to a first-tier supplier, which are a real hinge of vertical network [61].

The pivot function, assimilated to a "Hub firm" [48], or "Strategic Centre" [57] refers to the central nodal of a network. Miles and Snow [64] refer to the player in charge of the intermediary function as a "broker". This player fulfils three distinctive roles within the network: the role of "architect" (constitutes the network), that of "lead operator" (coordinates the companies) and that of "caretaker" (maintains the network and ensures its 
long-term survival) [65]. These functions are part of a horizontal relationship (cooperation), and can be carried out by one or more entities. For this reason, in a hierarchical organisational configuration, Fréry [36] prefers to use the concept of nodal, the formal organ for regulating transactional structures. This nodal - a single player - is responsible for three simultaneous functions: design (major strategic orientations and selection of other players involved), coordination (optimisation of links with the aim of limiting the costs inherent to the hierarchy), and control (dissuading opportunistic behaviour that could disrupt the overall effectiveness of the structure). The 1980s and 90s were characterized by a tendency by firms to re-focus on their core business activities [11]. This movement gave rise to a "cooperative" relationship network, based on the need to engage the services of external suppliers, which in turn modified traditional subcontracting relationships. Thus, this enables the development of intermediation function of the first-tier supplier. By re-focusing on its core business activities, the architect has given up some of its key knowledge and is no longer able - for certain strategic sub-systems - to determine the interfaces and specifications unilaterally [71]. Bearing in mind all these elements, we can describe some first-tier supplier as Pivot-Firm. A Pivot-Firm is a "strategic partner which, on the one hand, co-designs the sub-system under its responsibility with the Integrator, co-specifying the required interfaces, and, on the other hand, develops strategic and combinatory competences, in the framework of a hierarchical network" (Mazaud) [61].

\subsubsection{A key concept: the strategic competence}

Competence concept is based on a "resources-based view", which considers firms as collections of resources of various types $[72,89]$.

This theory emphasizes the firms' heterogeneousness, due to the specific resources possession that is to say asset, capabilities, process and knowledge $[9,10]$. The nature of these resources can lead to getting a lasting competitive advantage, in generating rents [73].

The difficult imitation (feature) of a resource fits into the knowledge's tacit dimension of the resource [74]. As the tangible resources are easy to imitate [75], the intangible dimension is a differentiation factor. That is why, resources have a strong cognitive dimension $[24,42,52,83]$.

By comparison, the organizational capabilities, that is to say ability to coordinate and integrate the whole firm's resources [18], is going to increase. What gives a firm its competitive advantage are not resources but rather its abilities to implement it [41]. Inspired by evolutionist analysis, the "dynamic capabilities" characterize the firm's ability "to integrate, build, and reconfigure internal and external competences to address rapidly changing environments" (Teece et al.) [86]. It seems appropriate to underline the adaptive and even defensive feature [26] of these capabilities. The latter are as routine repertoire, enabling a firm adaptation to environmental evolutions [86] by the technological and/or organizational problem resolution [85].

From then on, approach in terms of competence [34] sets up a proactive vision of resources. The Firm would have ability to change their own environment [44]. The core competences show the organization's collective learning, which are essential to "coordinate diverse productions skills and integrate multiple streams of technologies" [44,45]. Accordingly, Sanchez et al. [81] having a coherent theoretical corpus, they consider the firm as a system open on its environment. The firm's competence means its ability to durably coordinate the use of its resources, in adapting itself and acting on its environment, according to previously determining objectives $[29,80]$. Therefore, the strategic feature of competence consists of identifying, extending and using business opportunities [17], which are based on industrial strategic factors [4] and on environment. The strategic competence covers three key dimensions: contribution in value creation, scarcity [78] and lastly it is less easy to imitate [63]. Therefore, it appears obvious that the first-tier suppliers, as Pivot-firms, which control a strategic competence, have an undeniable advantage.

\subsection{Modularization of vertical sub-contracting relationship}

Modularity is a strategy to effectively organize complex products and processes [7,84]. The approach involves dividing a complex system into independently designed and produced units or modules, which are linked together 
via interfaces, i.e. "visible design rules", defining the place, the function and the interactive modes of each module [7].

Ulrich [87] defines product-architecture as the system via which "a product's function is allocated to physical components". Thus, the product architecture is an arrangement of functional elements, which contribute to the performance of the overall product. This product architecture is described as modular when the interfaces are linked, i.e. when there is an identity between the product's physical components and the functional elements of the system. The modification of one component does not lead to any modification of the linked component, nor of the system as a whole. However, the product architecture is said to be integral when the interfaces are not linked, i.e. there is no identity between the product's physical components and the functional elements of the system. Each component can carry out several functions and each function can be carried out by several components [35]. Thus, a productive modular organization is orchestrated by an architect-firm, making up the firm network that it needs to create the overall system [7].

Modularisation is becoming the dominant model in complex vertical relationships [53]. It enables the manufacturing process to be reorganized, based around standardized interfaces. This leads to increased flexibility [13], reduced production costs and lead times [39]. Finally, organisational modularity necessarily involves an organisational architecture based on the autonomous technological design of each module [82]. However, these analyses do not leave a lot of room for direct suppliers, which leads us to question the notion of interface.

The architect role becomes essential in the interface definition [37]. The interfaces can be assimilated to information.

According to Baldwin and Clark [7], in a modular perspective, the interface characterizes all the information - the "visible design rules" - which define the place, function and interactive modes of each of the modules, bearing in mind that other, invisible, information is specific to the design and production of each of the modules. The interface is thus considered a "pivot" between the producer's resources and the user's resources [56], which raises the question of the customer's access to the supplier's resources [5]. In the framework of subcontracting relationships, the notion of interface goes beyond the mere work specification and addresses the question of complementarity in terms of competences, i.e. the knowledge, experience and know-how of the individuals who make up the firm [77]. The interface between customer and supplier - more specifically, that between the orderer and the subcontractor - is crucial since, on the one hand, it depends on the nature of the modules exchanged and, on the other hand, it characterizes the relationship between the two firms [6,21]. Araujo, Dubois and Gadde [5] have identified several types of interface, from the standardized interfaces to interactive interfaces, via specified interfaces and translation interfaces. When the interface is standardized, it is a simple "buy and sell" interfaces, corresponding to standard products which have already been designed and produced by the subcontractor, and which are sold in the latter's "catalogue". The resulting relationship is therefore of the commercial type - a classic "arm's length" type relationship.

Opposed to the standardized interfaces, we find the interactive interfaces, when the specifications are drawn up jointly by the supplier and its customer. This leads to a common learning process, since the two entities interact, developing the ability to use the other's resources.

The more the interfaces are standardized; more the organizational configuration of customer-supplier relationship will be of modular type, giving space to flexibility, as well as to reduced cost and shorter lead-time.

Conversely, the more the interfaces trend towards interaction, the more organizational configuration will be of integral type. Thus, the customer-supplier relationships will be characterized by a lower flexibility and stepped-up production costs.

\subsection{The purchasing strategy}

Kraljic introduces in his 1983 article [50] a purchasing segmentation matrix, the first tool of the Strategic Purchasing Orientation (SPO). In an uncertain context, this matrix makes it possible to provide a "pragmatic advice on how to manage the extent of its own supply of weakness and treat it with a comprehensive strategy to manage supply" (Kraljic, p. 109) [50].

This model will become a tool for managing procurement processes in organizations $[28,70]$. 
The construction of the purchasing matrix proposed by Kraljic [50] takes place in four phases:

- Classification: It is a question of analyzing the impact of the supply item on the profits.

- Market Analysis: it's about analyzing the bargaining power of the supplier.

- Strategic positioning: for each product purchased, it is necessary to assess risks, identify areas of opportunity and vulnerability.

- Action plans: for each outsourced item it is necessary to determine areas such as the volume, the price, the selection of the supplier, the replacement of materials.

The Kraljic matrix will be supplemented and refined by numerous theoretical contributions, notably the criteria of risk and profitability $[49,68]$.

Although this first matrix will be complemented by vendor segmentation tools [51]. The indicators remain very static and never take into account the skills creation process, linked to the long-term relationship between customer and supplier [54] as observable in the aeronautics sector [62].

The dimension of complex products and systems (COPS) generate the need to maintain long-term relationships between customer and first tier supplier.

Thus, the mastery of a strategic competence by the supplier determines the purchasing strategy developed by the customer.

Kraljic's matrix and its subsequent developments, proposes a one-way analysis (top down) whereas for the COPS, the criteria of segmentation of purchases and suppliers are today conditioned by the nature of the competences held by the first-tier supplier (bottom to top).

It is therefore possible to determine an optimal purchasing policy, an optimal ordering policy which is a function of the risks to impact the total cost [47].

However, the expression of the needs of the prime contractor is often fuzzy and imprecise (imprecise fuzzy demand) which increases the different supply-chain costs. These costs decrease with the effect of experience (decreases due to learning effects). The prime contractor is therefore seeking to optimize the quantities of products requested from its leading supplier by reducing as much as possible the costs related to uncertainty and blurring [25].

\subsection{The impact of the purchasing strategy on vertical sub-contracting relationship, which entails a dual coordination mode}

The firm has split up into function parts (research \& development, production, finance, procurement, etc.). Each function has to reach the goal, which a global and long-term strategy. For each of these functions, particular strategy has to be implemented. Some constraints (suppliers, competitors purchasing strategy, general firm's strategy) and some means (purchasing budget) impose upon it. This purchasing strategy comes in a variety of purchasing policies in accordance with a strategic segmentation of purchases. This segmentation is often based on the technological nature of the component families, integrating analysis of the technological competences controlled by the suppliers, or even the risks linked to competitors. Next, the key success factors for each segment have to be determined (costs, quality, lead time, related services, etc.). An individual strategy is then developed for each segment, ensuring that each strategy remains strictly consistent with the firm's general strategy [58]. For each homogeneous family of purchasing, a specific policy will be implemented by the objective fixing (growth rate, profitability) and means determining (financial and human).

In a modular approach, the product is divided in sub-systems, classed according to their strategic importance. According to Venkatesan [88], there is a strategic difference between these segments, according to the specific impact they have on the firm's competitiveness. The strategic sub-systems have a direct influence on the main attributes (including cost) of the final product. They are inputs with the highest added value, linked to the selling firm's main area of competence, and can be useful for differentiating the final product [31]. They require a highly specialized design, and therefore, very specific competences and assets.

On the other hand, non-strategic sub-systems mainly develop mature technology. They are relatively standardized inputs, and only require a slight degree of inter-dependency between supplier and customer: the need 
for coordination is therefore low [31]. Their specialized design does not have a very strong impact on the final product in terms of differentiation.

Each purchasing strategy leads to the set-up of a better supplier policy. That means a segmentation of potential supplier range, in homogeneous family according to diverse criteria (price, product, supply, etc.). The strategic degree of the subcontracted segments influences the choice between a single or multi-source policy, bearing in mind that for the most strategic segments, there are very few independent suppliers with the competences required for their design and development. In accordance with the opposition between the Japanese and American models [20,30,31], we can distinguish two types of supplier relationships. The traditional approach, known as Arm's Length, which dominated until the late 1980s, gives absolute priority to cost. The architect "steers operations", in a balance-of-power relationship, maintaining technical control over the product and providing itself with the means to modify its choice of suppliers (multi-source procurement), depending on the cost factor. The architect acts as a real Orderer, ensuring that interfaces are as standardized as possible in order to obtain a flexible supplier network and reduce its costs [79].

Since the late 1980s, the fact that firms have tended to re-focus on their core business, and the vertical disintegration of activities, have given rise to the development of strategic alliances $[48,76]$. Indeed, for the most strategic segments, partnerships (almost hierarchical) have been set up. Cost is no longer a decisive factor - it has been replaced by the notion of "total acquisition cost", covering all the costs incurred by the procurement (cost, quality, lead times, after-sales service, problems) [32]. This duality in terms of coordination modes for vertical relationships is at the centre of the distinction we make between modularisation and systems integration [38].

The Vanishing Hand model [53] considers the architect firm as an Orderer, defining ex ante the parameters of each of the delegated modules, standardizing the interfaces as far as possible, in order to reduce the costs linked to coordination and production of the final product. This organisational configuration corresponds to a technical division of the work, combined with striving to reduce costs to a minimum (the modules are interchangeable). Langlois [53] defines the coordination mode relative to modular-type decentralized production observed in the 1990s as "vanishing hand". This is an intermediary coordination situation - not entirely free but not entirely integrated - with the established domination of the commercial relationship, and it is therefore similar to an Arm's Length type strategy.

The approach in terms of systems integration focuses on firms, which produce complex products (CoPS) [27]. Prencipe [76] defines the systems integrator as an "organisation that builds up the network and controls it from an organisational and technological point of view". The integrator develops partnerships with the suppliers of the most strategic sub-assemblies: it corresponds therefore to a strategic-type alliance [33]. According to Prencipe [76], this model is based on a resources-based view, which considers firms as collections of resources of various types [72]. Firms are thus considered as integrators of internal or external information and knowledge [66].

From a strategic point of view, the systems integrator configures the network as regards the number, type (direct or indirect) and intensity of relationships [14]. In practice, this distinction between coordination modes is not always easy to make: the architect can be the Orderer or the Systems Integrator, depending on the type of sub-assembly delegated.

\section{Methodological approach}

\subsection{Case selection}

This contribution comes along with a case study, which represents a qualitative analysis of several specific elements that influence the long-run relationship of mutual interest between principals and sub-contractors in the aerospace industry.

For this purpose, we examined the relationship between Airbus Company and its main suppliers.

In a multi-client model in which a company can provide products to multiple customers (multi-customer supply chain inventory model where a company can supply products to multiple customers), it is possible to optimize the supply chain [15]. 
Our empirical study focuses on a supply chain model Models focus on two-stage chains, with bilateral relations centered either on cooperation or on costs.

\subsection{Data sources and analysis}

We conducted approximately 40 interviews with the Airbus Company and the main first tier suppliers: Goodrich Aerospace Europe (UTC), Safran Electrical \& Power, Sogeclair Aerospace, Latécoère, Rockwell Collins France, Honeywell Aerospace, Liebherr-Aerospace Toulouse, Ratier Figeac and Thalès Avionics.

The limits of our data-sources and interviews are of several kinds.

First of all, the analysis remains circumscribed to the analysis of the Airbus purchasing strategy with nine of its major third-party firms. Our model is not exhaustive. However today, Airbus is working with only about fifteen firms-tier suppliers around the world.

We conducted individual interviews with the main purchasing managers at Airbus and the various supply chain managers of the First-Tier supplier.

Many strategic data are confidential including those that fall under the criteria of selection of suppliers. We therefore remained deliberately neutral in a transcription of these purchasing strategies.

Given the sensitivity and confidentiality of the data, our questionnaires were essentially qualitative. This is not necessarily a limit because the purpose of this article is not to develop a new purchasing strategy matrix but to understand the motivations of the strategic choice of suppliers.

The analysis of the interview firms' experience with collaborative initiatives provided insight into the motivations of collaboration.

These empirical analyses confronted with the theorical model enables us to throw light on concept of Pivot Firm, but also to explain the success and the constraints of collaborations within the supply chain.

These results made it possible to make a distinction between First-Tier Suppliers.

\section{FINDINGS}

\subsection{Airbus France - First-Tier supplier: a dual architectural relationship}

In the late 1980s, Airbus re-focused on its core business as an aircraft manufacturer - general design, cockpit, avionics, engine pylons, final assembly, certification, etc., and proceeded to outsource those activities which it judged non-strategic. In order to remedy a certain lack of consistency and efficiency regarding its subcontracting policy, Airbus elected, in 1993, to rationalize its purchasing, the objective being to reduce the number of direct subcontractors from six hundred and ninety to around one hundred by the year 2000 [2]. This movement occurred at the same time as the setting up of a pyramid-shaped industrial architecture, with the development of "general subcontracting", which consisted in a transfer of responsibility to the equipment supplier as regards financing (risk sharing, Alcouffe, 2002) ${ }^{2}$ [1], development, production and responsibility for the complete subassemblies (including the organization of its own sub-contracting network) [23]. From 1995, cross-functional progress measures known as CAP (growth and adaptation through processes) and CAP 2001 were implemented, with the aim of reducing procurement costs by 12 to $15 \%$ by 2001 . These measures continue to the present day through the Road 06 and the latest Power 8 programme. This rationalization has led Airbus to modify its organization and divide its purchasing into five categories:

\footnotetext{
${ }^{2}$ The most common form of risksharing is the "Non Recuring Costs" (NRC): the physical interface provides financial support for the development and industrialization of the module under its responsibility. These costs are passed on to the sale price of the module; however, they are based on forecast sales (expenditure to be recovered over x-number of aircraft). If sales do not reach the level of the forecasts, the intermediary bears the resulting losses.
} 
- "Aerostructures", organized into Centres of Excellence spread over the various production sites ${ }^{3}$, and specialized in the production of a particular section. Each Centre delegates "Work Packages" to Aerostructure suppliers, i.e. complete sub-assemblies ( $80 \%$ of aerostructure subcontracting), while the rest (detail parts, electrical assemblies and interiors) is outsourced to a variety of subcontractors.

- "Equipment items" are line replacement units that have a function within the aircraft structure. This category covers "traditional" mechanical equipment items (hydraulics, air conditioning, landing gear, etc.) produced by equipment suppliers, and all avionics systems (on-board electronics, computers) produced by system suppliers.

Embedded system: computer systems that form an integral part of a product (hardware) with software etc. Avionics is an application of an embedded system for the navigation and control of aircraft. The onboard electronics used for piloting an aircraft are called avionics (aviation electronics). Avionics include communications and navigation systems, autopilots, and electronic flight management systems (FMS). Onboard electronics that are unrelated to piloting tasks, such as video systems for passengers, are sometimes considered avionics as well. Many of these devices include embedded computers. The term is also used to define the electronics units fitted to a spacecraft.

So, in accordance with this distinction between embedded systems, the competition between aircraft manufacturers is increasingly based on the differenciation power related to the embedded systems.

- "General Procurement" is difficult to outsource in a general way - however, the current trend is to outsource complete assemblies, transport, communication, etc.

- Engine: this equipment category involves a particular \& specific relationships bewtween engine manufacturers and Airbus. This relationship cannot be called sub-contracting, because of the engine manufacturer power.

- "Materials" in this case, it is are a traditional / classic procurement. Nevertheless, many strategic materials entail international cooperation (like Titanium, composite,).

\subsection{Towards a more efficient supply-chain management: the Equipments and Systems purchases}

\subsubsection{The Airbus purchasing strategy...}

The Airbus purchasing strategy has two main features:

- Suppliers selection process for Equipments and Systems:

The Airbus supplier selection process is applicable to any supplier willing to do busines with Airbus. The Airbus supplier selection process comprises the following steps:

- The signature of the Non-Disclosure Agreement (NDA) between Airbus and suppliers initiates the supplier selection process to protect the data exchanged.

- Potential suppliers data is collected via the launch of Airbus Request of Information (RFI) and/or Request for Technical Information (RFTI).

- A short list is then created based on market analysis, offset requirements and previous experience with the supply base. The short-listed supliers are then sent an Airbus request for Proposal (RFP).

- Responses from suppliers to the RFP are evaluated against specific criteria based on the technical, quality, contractual and commercial requirements of Airbus.

- Transversality of purchasing:

\footnotetext{
${ }^{3}$ Wings in the UK (Bristol and Chester-Broughton), rear fuselages, customisation and assembly of single-aisle Airbus aircraft in Germany (Hamburg, Bremen and Brunswick), stabilizers and belly fairings in Spain (Madrid, Cadix) and, in France, machining of the nose and forward fuselage section in Méaultes, centre fuselages in Nantes and Saint-Nazaire, and final assembly, flight testing and certification in Toulouse.
} 
In this framework, cross-functional teams - the Multi-Functional Teams (MFT) - manage the purchasing activities of a given segment in a flexible way, their main objectives being to increase efficiency and reduce procurement costs. These MFTs are divided firstly into Project Management Groups (PMG), responsible for steering an even more specific segment of the project, then into Integrated Project Teams (IPT), responsible for the development and production of specific items. These IPTs meet on design platforms and integrate both Airbus personnel and equipment suppliers. This is a "concurrent engineering" process aimed at the collaborative development of products. Their perimeter varies depending on the stage of the project or the difficulties encountered. However, it would clearly appear that the purchasing segments do not all have the same strategic importance for Airbus, depending on their added value and respective ability to differentiate the final product.

\subsection{2. ... impacts the Airbus Supply Chain Management ...}

The Airbus supply chain management contemporary has the following characteristics:

- A reduction in the number of direct suppliers:

Currently, a European process of reorganization and concentration is being set up in parallel with that taking place in the United States (acquisition of Mac Donnell Douglas, Rockwell and Hugues by Boeing and internal reorganization of the firm which is structured around large divisions each with its relatively autonomous management: commercial aircraft defense, space ...).

In this general reorganization, the Airbus Architect retains the noble activities, with high strategic content (design, final assembly, test and certification, specific productions).

In recent years, the general volume of manufacturing activities tends to be reduced, the aircraft manufacturer increasingly outsources the implementation of parts of the aircraft structure.

Purchases are becoming increasingly important in the cost of aircraft: more than $70 \%$ of equipment and systems and $50 \%$ of aerostructures are subcontracted.

Thus, in order to reduce production costs, the main principals (Airbus and its system operators) have considerably reduced the number of their direct suppliers, entrusting them with the task of organizing the entire production process of the modules provided.

A densification of the rank 1 stratum is now observable, with a small number of equipment manufacturers and system builders. This allows the aircraft manufacturer to further reduce its production costs by rationalizing them.

- Strengthening the hierarchy of the supply chain:

The majority of equipment manufacturers develop with Airbus a traditional activity of manufacturing on specification, which does not mobilize a thorough R \& D. But for this, they have a direct relationship with the aircraft manufacturer. They do not master the entire production process and lack in particular designer autonomy.

Close relations are nevertheless maintained with the prime contractor for the compliant implementation of the contracts, without it being a partnership relationship.

Faced with the recent densification of the first rank layer, linked to their international competition, some are looking to evolve into a systems activity (co-design of the subset), in order to develop a direct relationship (much more stable). with Airbus.

To do this, they need to develop their design skills in order to master the entire production process of an integral system to the final product. This husbands in return the financial resources needed to support R\&D. Hence the increased concentration of large industrial groups at the level of rank 1.

- Increased competition from first-tier suppliers:

The equipment manufacturers and system operators bear the brunt of the rationalization of supply policy, operated by the aircraft manufacturer. Thus, tenders are now expanded to international competition.

The option is open to European-sized suppliers in Germany, Great Britain and Spain. 
For example, the interruption of relations between Airbus and Goodrich Aerospace Europe, as regards the construction of the nacelles of reactors. Goodrich Aerospace Europe has accompanied Airbus since the launch of its first programs in the 1970s.

Despite the responsiveness and adaptation of the equipment manufacturer (lower costs, shorter delays, reorganization of production, etc.), Airbus preferred to approach the firm Hurel Hispano to found Aircelle, a direct competitor Goodrich implanted like him, close to the assembly lines.

Another revealing element of this competition of equipment manufacturers is the significant development of European and North American branches of equipment manufacturers (especially industrial manufacturers) close to the aircraft manufacturer. It is for them, to provide commercial intermediation, but also maintenance services.

The objective of these commercial branches is to be recognized in the framework of tenders.

\subsection{3. ... and the Airbus Business Management System}

These changes in the supply chain management will lead to profound changes to the Airbus business management system:

- A strategic refocus on the heart of skills:

The general strategy of Airbus revolves around two essential points:

Competition with Boeing generates constant pressure for dual competitiveness. The reduction of production costs therefore becomes a major imperative. However, differentiation is also at the heart of Airbus' strategy.

In addition, research and the penetration of new markets becomes fundamental for Airbus. Production units have been established in China, India and Brazil according to the requirements of the local authorities. This is a disadvantage in the sense that there is a risk of capturing Airbus know-how by local players, but also an advantage because Airbus can thus reduce its production costs, or even research (Research Center in Bengalor).

Airbus is today a systems integrator. That is to say, the company has progressively refocused on its core competencies: the design and integration of systems.

Since the aircraft manufacturer has the vast majority of the systems it integrates, it imposes on its suppliers strong price reductions. This reduction cascades through the entire subcontracting chain. This leads many Airbus co-contractors to supply themselves in low-cost countries, with parts, the most standard elements.

These imperatives will then transcend the Airbus Business Management System, which now meets three essential criteria:

- Focus on its core business by outsourcing all the functions and productions considered as little or not strategic (cost reduction logic).

- Develop cooperation with First-tier suppliers who produce strategic equipment and systems.

- "Keep the hand" on the design of strategic elements, while doing so. Thus, when launching new programs, the first-tier suppliers realize the design tasks of their respective modules directly on the Airbus site in collaboration with the Airbus engineers.

- Optimization of supplies:

The air transport crisis at the end of 2001, as well as the global logic of profitability (driven by the EADS level), calls into question the close relations that Airbus' national entities have had with local manufacturers until now.

A policy of rationalization of supplies is therefore implemented by Airbus which, for the sake of profitability, requires from all these suppliers, an increased reduction in production costs.

From now on, a common purchasing department coordinates the 10 technical areas of skills, by specialty.

The main principles of the strategy of rationalization of supplies engaged by the aircraft manufacturer is concretized by a reduction of the number of direct suppliers, as well as by various measures: 
- an extension of calls for tenders to foreign competition,

- greater use of catalogue purchases (standard products),

- joint purchases between Airbus and its main subsidiaries,

- information sharing in real time.

- A growing sharing of financial risk:

Today, the contractors transfer financial responsibility for the development of subsets to the first-tier suppliers, in order to optimize their purchasing policy and minimize the total cost [19]. First-tier suppliers are thus assuming more and more risks.

The most common form of risk sharing is the "Non-Recurring Costs" (NRC): the physical interface provides financial support for the development and industrialization of the module under its responsibility. These costs are passed on the price of the module; however, they are based on forecast sales (expense to be recovered over $\mathrm{x}$-number of aircraft). If sales do not reach the level of the forecasts, the intermediary bears the resulting losses.

The sharing of financial risk is now an integral part of the purchasing policy but also of the sales policy.

In a two-tier supply chain, the prime contractor is sensitive to the promotional efforts of its supplier. The cost of purchasing a subset is then calculated based on sales forecasts for a certain number of aircraft. According to Cárdenas-Barrón, and Sana [16], the profit expected by the supplier thus integrates all of these parameters cost setup, holding cost, selling price, and promotional cost shared.

\subsubsection{The coordination of the relations between the members of supply chain.}

Synthetically, the airbus supply chain consists of several categories of suppliers:

- First-tier suppliers: Latecoere, Liebherr Aerospace, Hamilton Sundstrand, etc.

- Second-tier suppliers: Sudaero, Rossi Aero, Ségnéré, etc.

- Engineering service suppliers: Altran, Sogeclair, AKKA, Safran, etc.

- Suppliers of composite materials: Stelia Composites, Aero Compsite, etc.

- Suppliers of raw materials: (foundries and forges) Taramm, Aubert and Duval, Ventana, etc.

The strategic segmentation of purchasing drives Airbus to develop a multilateral management of its direct suppliers according to various issues.

- The first-tier suppliers are coordinated according to the strategic nature of the skills mastered. The more this expertise complements Airbus' core competences, the more this relationship will be of the partnership type (Risk Sharing Partner). Therefore, for Airbus, the purchase costs will be higher. The more the skill mastered by the first-tier supplier is standard, the more the relationship will be coordinated according to cost considerations.

- The relationship with second-tier suppliers is coordinated by the first-tier suppliers. This relationship is based almost exclusively on cost criteria. However, the second-tier supplier can sometimes look for specific skills with second-tier suppliers.

- Engineering service providers are in direct contact with Airbus or with first-tier suppliers. They are often coordinated according to cost criteria, which pushes them to outsource all or part of their services.

- Suppliers of composite materials, are in direct contact with Airbus or with first-tier suppliers, or even with second-tier suppliers. They are coordinated according to cost criteria but also to quality of the materials. A specific qualification is imposed on suppliers of composite materials. Airbus provides a pre-established list of suppliers of composite materials to its first-tier suppliers or second-tier suppliers.

- The suppliers of raw materials are themselves suppliers of first-tier suppliers or second-tier suppliers and very rarely have direct relations with Airbus. From the moment they meet the quality standards, the coordination of relations is almost exclusively on a cost criterion.

Thus, the coordination of relations differs according to the "function", the position and the nature of the product made by the supplier. 
Airbus coordinates relationships with its direct suppliers based on the strategic level of subcontracted subassemblies. The closer this subset is to the aircraft manufacturer's core competency, the more coordination will be based on the supplier's skills, to the detriment of the cost of production.

First-tier suppliers must coordinate second-tier suppliers. The closer the subcontracted element is to the core competencies of the first-tier supplier, the more the coordination is based on skills, to the detriment of costs.

In the supply chain, the quality criteria required are increasing. From the moment a supplier is qualified, the coordination of the relations is realized essentially on criteria of costs.

\section{Discussion}

In this very hierarchical organization, Airbus has ensured that the most strategic competences remain internal (wing, vertical and horizontal stabilizers, engine integration, fuselage sections, on-board electronics, flight control computers, avionics, etc.) - such competences constitute its "Core Business". Nevertheless, $70 \%$ of the cost of an aircraft is purchased externally. As the Architect, and in order to rationalize procurements, the aircraft manufacturer deals almost exclusively with first-tier full suppliers, which are responsible for the development, financing and production of complete sub-systems. The strategic segmentation of its purchasing activities has led Airbus to apply a similar segmentation as far as its suppliers are concerned [90].

\subsection{Systems Integration relationships}

This kind of relationship is a matter of the most strategic first-tier supplier. They manufacture strategic equipments \& systems of which Airbus owns a competence in design conception. The major equipments and systems suppliers produce strategic sub-assemblies such as avionics systems, with Thalès Avionics or Rockwell Collins, for example, or certain sensitive equipment items (aerostructures or mechanical equipment), such as fuselage parts, with Latécoère, or air conditioning systems with Liebherr Aérospace, in particular. Thalès Avionics, thanks to these competences in avionics, is the best example of strategic first-tier supplier. The typical example of a strategic partner is Thalès-Avionics, which has developed perfect technical control of on-board systems. Indeed, Thalès Avionics disposes complementary competences to the aircraft manufacturer that enables a value added to the Airbus final product. These first-tier suppliers, in possession of real strategic competence with a high added value, are pivot-firms [61]. Airbus develops strategic partnerships with them.

In this relationship Airbus acts as systems integrator. Production of the most strategic systems and equipment items (on-board electronics, air conditioning, certain parts of the structure, etc.) leads Airbus to work with pivotfirms in order to jointly specify the interfaces and determine the work specifications, the conditions required to ensure correct integration of these sub-systems in the overall product as well as their interconnection. This gives rise to a genuine strategic partnership. Airbus maintains its general design and control prerogatives, but relinquishes its coordination function in favor of pivot-firms, which are the only entities capable of combining the competences required for the design and development of the sub-assemblies under their responsibility. The systems integration relationships are mainly based on the first-tier supplier possession of strategic competences.

\subsection{Arm's length relationships}

The Arm's length relationships are described by Dyer and Singh [32]. According to them "Arm's length market relationships are characterized by:

- non-specific asset investments

- minimal information exchange (i.e., prices act as coordinating devices by signalling all relevant information to buyers and sellers),

- separable technological and functional systems within each firm that are characterized by low levels of interdependence (i.e., the two organizations have only a sales-to-purchasing interface and do not jointly create new products through multifunctional interfaces),

- low transaction costs and minimal investment in governance mechanisms (Williamson, 1985)". 
This kind of relationships is relevant to the less strategic first-tier supplier. Airbus acts as an Orderer, providing a very precise description of the interfaces (which may be specified or translation interfaces) and the work specification, and leaving little room for maneuver for its subcontractors, which are mainly selected on a cost basis. Furthermore, they are frequently forced into competition with one another, through a benchmarking system ${ }^{4}$. As regards less strategic equipments suppliers, Airbus aims to reduce its coordination costs and therefore limits its role to simply being aware of the lower tier subcontractors who have been selected in order to reduce its costs.

The interdependence of first tier relationships allows the maximization of benefits for the customer and the supplier [59]. This cooperation between the prime contractor and its first-tier supplier then generates development costs to improve the reliability of the production system.

In addition, the cooperation between the architect and the first-tier supplier generates development costs to improve the reliability of the production system as a whole [60].

\subsection{Airbus, a dual firm}

According to Cohendet \& Llerena [22], the two preceding approaches are more complementary than opposite. A same firm can simultaneously create and allocate resources i.e. manage competences and transaction. "In this "dual" vision..., first [the firm] focused on the bulding of the domain of core competence...giving full priority to the creation of resources. Then, ... the firm tends to allocate resources and to adapt to the environment in accordance with governance mechanisms that are well analysed by the transaction cost approach" (Cohendet \& Llerena, pp. 176-77) [22].

Airbus can be apprehended like a dual firm because of its dual management of procurement. In spite of a dual management of relationships with first-tier supplier, ambition to reduce cost of purchasing is omnipresent. However, it has to respond to important requirements in terms of quality and environment. In addition to the international quality standards in force, the reliability of sub-assemblies is ensured by a very strict supplier evaluation system, known as "rating", which is managed by the various "Purchasing" divisions within Airbus. The equipment suppliers are rated according to total quality criteria (quality, costs, lead times and control over industrial risks) further to annual audits.

\section{Conclusion And Future WORK Directions}

Competition and financial profitability constraints the Orderers to only solicit a limited number of suppliers, which must cover a larger area of responsibility. The structure of production organization becomes more hierarchical and coordination modes seem to move towards a single model for the transaction costs' reduction. While on a theoretical level it allows for greater visibility, in practice, a modular approach cannot guarantee a sufficient insight into the coordination modes with first-tier suppliers. By integrating purchasing strategy into our analysis, we have shown the diversity and continuity in coordination modes. This relational mixing is at the core of Airbus' segmentation.

The emergence of more and more strategic stakes involves a new structuring of vertical sub-contracting relationships.

Procurement in Airbus, and particularly equipment \& systems' purchases has a major importance by becoming a key competence.

The strategic dimension inherent in purchasing, leads to a fine a more differentiated management of the supply chain. This key competence lies at the crossroads of two aspects:

- A significant reduction in transaction costs for non-strategic market segments (a relationship based on cost for non-strategic equipments and systems).

\footnotetext{
${ }^{4}$ Benchmarking shall consist of "finding, at international level, the company(s) that perform a given task or process in the most efficient way, going to study the way they perform such task or process", for as long as its prices remain competitive. Price benchmarking is relatively common, and is necessary to maintain a healthy level of competition between two or three suppliers.
} 
- The development of mutual learning, founded on cognitive coordination on strategic segments (a relationship based on competence for strategic equipments and systems).

These significant changes, which are both cognitive and organizational, are occurring in parallel to other global transformations of the capitalist system. Thus, the movement of international sub-contracting gains in importance/momentum with supplier being located in different areas depending on the nature of their production.

This work could subsequently be supplemented by an analysis of the gradual reconfiguration of the industrial landscape. The industrial organization is tightening at the top. Major contractors (Airbus, Boeing, etc.) now working in single or maximum dual source. This leads to a reduction in the number of first tier suppliers as well as to the increase of their size. The question of the increasing transfer of responsibilities (finance, quality, selection of suppliers, etc.) from the client to the First-tier suppliers arises.

Acknowledgements. I extend my sincere thanks to the anonymous reviewers for the quality of their remarks. My thanks also go to the Airbus Equipments and Systems Purchasing teams, Thales Avionics, Goodrich Aerospace Europe (UTC), Safran Electrical \& Power, Sogeclair Aerospace, Latecoere, Rockwell Collins France, Honeywell Aerospace, LiebherrAerospace Toulouse, Ratier Figeac and Thalès Avionics for the quality of their welcome and their confidence.

\section{REFERENCES}

[1] C. Alcouffe, L'organisation de la R\&D entre marché et hiérarchie. Evolutions de la relation client-fournisseur et forme de coopération dans l'aéronautique et le spatial. In: Marché(s) et hiérarchie(s), edited by M. Saboly and L. Cailluet. Presses de l'Université Toulouse 1 Sciences Sociales, Toulouse (2002) 275-288.

[2] C. Alcouffe and N. Corrégé, Structures de gouvernance dans l'entreprise étendue: l'exemple d'Airbus. Notes du LIRHE 393 (2004).

[3] C. Altersohn, La sous-traitance à l'aube du XXIième siècle. Dynamiques d'Entreprises L'Harmattan (1997).

[4] R. Amit and P.J.H. Schomaker, Strategic assets and organizational rent. Strat. Manage. J. 14 (1993) 33-46.

[5] L. Araujo, A. Dubois and L.E. Gadde, Managing interfaces with suppliers. Ind. Marketing Manage. 28 (1999) $497-506$.

[6] B. Asanuma, Manufacturer-supplier relationships in Japan and the concept of relation-specific skill. J. Jpn. Int. Econ. 3 (1989) $1-30$.

[7] C. Baldwin and K. Clark, Managing in an Age of Modularity, edited by R. Garud, A. Kumaraswamy and R.N. Langlois. In: Managing in the modular age. Blackwell Publishing, Oxford, (1997) 149-161.

[8] C. Baldwin and K. Clark, Design Rules: The Power of Modularity. The MIT Press, Cambridge, Massachusetts (2000).

[9] J.B. Barney, Strategic factor markets: Expectations, luck, and business strategy. Manage. Sci. 32 (1986) $1231-1241$.

[10] J.B. Barney, Firm resources and sustained competitive advantage. J. Manage. 17 (1991) 99-120.

[11] L. Batsch, Le recentrage: une revue. Cahiers de Recherche du CEREG (2002).

[12] B. Billaudot and P.A. Julien, Organisation industrielle et sous-traitance: du fordisme à l'entreprise-réseau, edited by P.A. Julien, R. Jacob, L. Raymond and G. Abdul-Nour. In: L'entreprise-réseau, dix ans d'expérience de la Chaire Bombardier Produits récréatifs. Presses de l'Université du Québec (2003) 47-71.

[13] S. Brusoni and A. Prencipe, Modularity in complex Product systems: Managing the Knowledge dimension. Working Paper CoPS Publication 57 (1999).

[14] S. Brusoni, A. Prencipe and K. Pawitt, Knowledge specialization, organizational coupling and boundaries of the firm: Why do firms know more than they make? Adm. Sci. Q. 46 (2001) 597-621.

[15] L.E. Cárdenas-Barrón, Optimizing inventory decisions in a multi-stage multi-customer supply chain: A note. Transp. Res. Part E: Logist. Transp. Rev. 43 (2007) 647-654.

[16] L.E. Cárdenas-Barrón and S.S. Sana, Multi-item EOQ inventory model in a two-layer supply chain while demand varies with promotional effort. Appl. Math. Model. 39 (2015) 6725-6737.

[17] B. Carlsson and G. Eliasson, The nature and importance of Economic Competence. Ind. Corp. Change 3 (1994) 687-711.

[18] A.D. Chandler, Scale and Scope: The Dynamics of Industrial Capitalism. Harvard University Press (1990).

[19] K.J. Chung, L.E. Cárdenas-Barrón and P.S. Ting, An inventory model with non-instantaneous receipt and exponentially deteriorating items for an integrated three-layer supply chain system under two levels of trade credit period. Int. J. Prod. Econ. 155 (2014) 310-317.

[20] K.B. Clark, Project scope and project performance: the effect of parts strategy and supplier involvement on product development. Manage. Sci. 35 (1989) 1247-1263.

[21] K.B. Clark and T. Fujimoto, Product development performance. Strategy, organization and management in the world auto industry. Harvard Business School Press (1991)

[22] P. Cohendet and P. Llerena, A dual theory of the firm between transactions and competences: Conceptual analysis and empirical considerations. Revue d'Economie Industrielle 110 (2005) 175-198.

[23] G. Colletis and Y. Lung, La France industrielle en question. Analyses sectorielles. La Documentation française (2006). 
[24] K.R. Conner and C.K. Prahalad, A Resource-based theory of the firm: Knowledge versus opportunism. Organ. Sci. 7 (1996) 477-501.

[25] B. Das, An integrated supply chain model under fuzzy chance constraints. Adv. Model. Optim. 16 (2014) $113-132$.

[26] I. Dierickx and K. Cool, Asset stock accumulation and sustainability of competitive advantage. Manage. Sci. 35 (1989) 15041511.

[27] G. Dosi, M. Hobday, L. Marengo and A. Prencipe, The Economics of Systems Integration: Towards an Evolutionary Interpretation, edited by A. Prencipe, A. Davies and M. Hobday. In: The business of systems integration. Oxford University Press (2005) 95-113.

[28] P.R. Drake, D.M. Lee and M. Hussain, The lean and agile purchasing portfolio model. Supply Chain Manage.: Int. J. 18 (2013) 3-20.

[29] T. Durand, L'alchimie de la compétence. Revue Française de Gestion 160 (2006) 261-292.

[30] J.H. Dyer, Does governance matter? Keiretsu alliances and asset specificity as sources of Japanese competitive advantage. Organ. Sci. 7 (1996) 649-666.

[31] J.H. Dyer, D.S. Cho and W. Chu, Strategic supplier segmentation: The next best practice in Supply Chain Management. Calif. Manage. Rev. 40 (1998) 57-77.

[32] J.H. Dyer and H. Singh, The relational view: cooperative strategy and sources of interorganizational competitive advantage. Acad. Manage. Rev. 4 (1998) 660-679.

[33] J.H. Dyer, P. Kale and H. Singh, How to make strategic alliances work. Sloan Manage. Rev. 42 (2001) $37-43$.

[34] N.J. Foss, Capabilities and the Theory of the Firm. DRUID Working Paper 96-8 (1996).

[35] K. Foss, Modular Product Design: Creating Technologically Separable Interfaces. DRUID Working Paper (1998).

[36] F. Frery, La Chaîne et le Réseau, edited by P. Besson. Dedans, Dehors, Vuibert (1997) 23-53.

[37] V. Frigant, La modularité: un fondement pour des firmes architectes? Cahiers du GRES (2004).

[38] V. Frigant, Vanishing hand versus systems integrators. Une revue de la littérature sur l'impact organisationnel de la modularité. Revue d'Economie Industrielle 109 (2005) 29-52.

[39] T. Fujimoto and A. Takeishi, Modularization in Auto Industry: Interlinked Multiples hierarchies of Product, Production and Suppliers Systems. Working Paper CIRJE-F-107 (2001).

[40] C.J. Gelderman and A.J. Van Weele, Handling measurement issues and strategic directions in Kraljic's purchasing portfolio model. J. Purch. Supply Manage. 9 (2003) 207-216.

[41] R.M. Grant, The resource-based theory of competitive advantage: implications for strategy formulation. Calif. Manage. Rev. (1991) 114-135.

[42] R.M. Grant, Toward a Knowledge-based theory of the firm. Strat. Manage. J. 17 (1996) 109-122.

[43] B. Guilhon, Technologie, organisation et performances: le cas de la firme-réseau. Revue d'Economie Politique 102 (1992) 563-592.

[44] G. Hamel and C.K. Prahalad, The core competence of the corporation. Harvard Bus. Rev. 68 (1990) $79-91$.

[45] G. Hamel and C.K. Prahalad, Competing for the Future. Harvard Business School Press (1994).

[46] K. Imai and Y. Baba, Systematic Innovation and Cross-border Networks, Transcending Markets and Hierarchies to Create New a New Techno-economic System. Séminaire Science technologie et croissance économique OCDE (1989).

[47] D.K. Jana, B. Das and K Maity, Fuzzy rough supply chain model under inflation and credit period with stock dependent consumption rate and partial backlogging shortages via genetic algorithm. Int. J. Comput. Sci. Math. 6 (2015) 555-580.

[48] J.C. Jarillo, On strategic networks. Strat. Manage. J. 9 (1988) 31-41.

[49] A. Kaufman, C.H. Wood and G. Theyel, Collaboration and technology linkages: A strategic supplier typology. Strat. Manage. J. 21 (2000) 649-663.

[50] P. Kraljic, Purchasing must become supply management. Harvard Bus. Rev. 61 (1983) 109-117.

[51] R. Krapfel, D. Salmond and R. Spekman, A strategic approach to managing buyer-seller relationships. Eur. J. Mark. 25 (1991) 22-37.

[52] B. Kogut and U. Zander, Knowledge of the firm, combinative capabilities, and the replication of technology. Organ. Sci. 3 (1992) 383-397.

[53] R.N. Langlois, The vanishing hand: The changing dynamics of industrial capitalism. Ind. Corp. Change 12 (2003) $351-385$.

[54] A. Larson, Network dyads in entrepreneurial settings: A study of governance of exchange relationships. Adm. Sci. Q. 37 (1992) 76-104.

[55] B. Lawson, P. Cousins, R. Handfield and K.J. Petersen, Strategic purchasing, supply management practices and buyer performance improvement: An empirical study of UK manufacturing organisations. Int. J. Prod. Res. 47 (2009) $2649-2667$.

[56] B. Loasby, The organization of capabilities. J. Econ. Behav. Organ. 35 (1998) 139-160.

[57] G. Lorenzoni and C. Baden-Fuller, Creating a strategic centre to manage a web of partner. Calif. Manage. Rev. 37 (1995) 146-163.

[58] J.M. Loubère et R. Perrotin, Stratégies d'achat. Sous-traitance, Partenariat, Délocalisation. Editions d'Organisation $5^{e}$ édition, Paris (2005).

[59] A.K. Manna, B. Das, J.K. Dey and S.K. Mondal, Two layers green supply chain imperfect production inventory model under bi-level credit period. Tékhne 15 (2017) 124-142.

[60] A.K. Manna, J.K. Dey and S.K. Mondal, Two layers supply chain in an imperfect production inventory model with two storage facilities under reliability consideration. J. Ind. Prod. Eng. 35 (2018) 57-73. 
[61] F. Mazaud, De la firme sous-traitante de premier rang à la firme pivot: une mutation de l'organisation du système productif Airbus. Revue d'Economie Industrielle 113 (2006) 45-60.

[62] F. Mazaud, De la firme-sous-traitante de premier rang à la firme pivot, l'organisation du système productif Airbus, Ph.D. thesis, University of Toulouse (2007).

[63] P.X. Meschi, Le concept de compétences en stratégie: perspectives et limites. Communication à la VIème conférence AIMS Montréal (1997).

[64] R.E. Miles and C.C. Snow, Organization: New concept for new forms. Calif. Manage. Rev. 28 (1986) 62-73.

[65] R.E. Miles, C.C. Snow and H.J. Coleman, Managing $21^{\text {st }}$ century network organizations. Organ. Dyn. 23 (1992) 5-20.

[66] P. Moati, Organiser les marchés, dans une économie fondée sur la connaissance: Le rôle clé des intégrateurs. Revue d'Economie Industrielle 97 (2001) 123-138.

[67] P. Moati, and E.M. Mouhoud, Les nouvelles logiques de décomposition internationale des processus productifs. Revue d'Economie Politique 5 (2005) 573-590.

[68] R.F. Olsen and L.M. Ellram, A portfolio approach to supplier relationships. Ind. Marketing Manage. 26 (1997) $101-113$.

[69] G. Paché and C. Paraponaris, L'entreprise en Réseau. Que Sais-Je? 2704 (1993).

[70] S.S. Padhi, S.M. Wagner and V. Aggarwal, Positioning of commodities using the Kraljic Portfolio Matrix. J. Purch. Supply Manage. 18 (2012) 1-8.

[71] K. Pavitt, Innovation Processes, edited by J. Fagerberg, D. Mowery and R. Nelson. In: Oxford Handbook of Innovation. Oxford University Press (2005) 86-147.

[72] E. Penrose, The Theory of the Growth of the Firm. Oxford University Press New York (1959).

[73] M. Peteraf, The cornerstones of competitive advantage: A resource-based view. Strat. Manage. J. 14 (1993) $179-191$.

[74] M. Polanyi, The Tacit Dimension. Doubleday New York (1966).

[75] M. Porter, Towards a dynamic theory of strategy. Strat. Manage. J. 12 (1991) 95-117.

[76] A. Prencipe, Corporate strategy and systems integration capabilities. Managing networks in complex systems industries, edited by A. Prencipe, A. Davies and M. Hobday. In: The business of systems integration. Oxford University Press (2005) 114-132.

[77] G.B. Richardson, The organization of industry. Econ. J. 82 (1972) 883-896.

[78] R.P. Rumelt, Theory, Strategy and Entrepreneurship, edited by D. Teece. In: The competitive challenge. Ballinger, Cambridge, MA (1987) 137-158.

[79] M. Sako, Modularity and Outsourcing: The Nature of Co-evolution of Product Architecture and Organisation Architecture in the Global Automotive Industry. In: The business of systems integration, edited by A. Davies, M. Hobday and A. Prencipe. Oxford University Press (2005) 229-253.

[80] R. Sanchez, Understanding competence-based management, identifying and managing five modes of competence. J. Bus. Res. 57 (2004) 518-532.

[81] R. Sanchez, A. Heene and H. Thomas, Dynamics of Competence-Based Competition: Theory and Practice in the New Strategic Management. Elsevier London (1996).

[82] R. Sanchez and J.T. Mahoney, Modularity, flexibility, and knowledge management in product and organization design. Strat. Manage. J. 147 (1996) 63-76.

[83] J.C. Spender, Making knowledge the basis of a dynamic theory of the firm. Strat. Manage. J. 17 (1996) 45-62.

[84] M. Starr, Modular production a new concept. Harvard Bus. Rev. 43 (1965) 131-142.

[85] D.J. Teece, Technological change and the nature of the firm. In: Technical change and economic theory, edited by G. Dosi, C. Freeman, R. Nelson, G. Silverberg and L. Soete. Francis Pinter, London, and, Columbia University Press, New York (1988).

[86] D.J. Teece, G. Pisano and A. Shuen, Dynamic capabilities and strategic management. Strat. Manage. J. 18 (1997) 509-533.

[87] K. Ulrich, The role of product architecture in the manufacturing firm. Res. Policy 24 (1995) 419-440.

[88] R. Venkatesan, Strategic sourcing: To make or not to make. Harvard Bus. Rev. (1992) 98-107.

[89] B. Wernerfelt, A resource-based view of the firm. Strat. Manage. J. 15 (1984) 171-180.

[90] J.M. Zuliani and G. Jalabert, L'industrie aéronautique européenne: organisation industrielle et fonctionnement en réseaux. L'Espace Géographique 2 (2005) 117-133. 